\title{
Change in the structural and functional properties of goat milk protein due to $\mathrm{pH}$ and heat
}

\author{
X. Y. Li, ${ }^{1} \odot$ M. Cheng, ${ }^{2}$ J. Li, ${ }^{1}$ X. Zhao, ${ }^{1} \oplus$ Y. S. Qin, ${ }^{1}$ D. Chen, ${ }^{1} \odot$ J. M. Wang, ${ }^{3}$ and C. F. Wang ${ }^{1 *} \odot$ \\ ${ }^{1}$ College of Food Science and Engineering, Qilu University of Technology (Shandong Academy of Sciences), Jinan, China, 250353 \\ ${ }^{2}$ Qingdao Research Institute of Husbandry and Veterinary, Qingdao, China, 266100 \\ ${ }^{3}$ College of Animal Science and Veterinary Medicine, Shandong Agricultural University, Taian, China, 271018
}

\begin{abstract}
This study was carried out to investigate the effects of $\mathrm{pH}$ and heat on the structure and function of milk proteins by comparing goat milk treated under different $\mathrm{pH}$ and temperature conditions. The results showed that $\mathrm{pH}$ had a significant effect on the thermal stability of goat milk proteins, and the proteins were least thermally stable at $\mathrm{pH}$ 7.7. Except for the $\mathrm{pH}$ 6.9 goat milk, the surface hydrophobicities of the milk proteins at various $\mathrm{pH}$ values reached their maxima at $85^{\circ} \mathrm{C}$. The particle size, zeta potential, and content of regular secondary structure also decreased significantly at $85^{\circ} \mathrm{C}$, and the turbidity of milk proteins under alkaline $\mathrm{pH}$ conditions was lower than that under acidic conditions. It was concluded that alkaline conditions resulted in better emulsion stability and oil-holding capacity, and acidic conditions offered better foaming ability, foam stability, and water-holding capacity for goat milk protein during heat processing. It can also be seen that $85^{\circ} \mathrm{C}$ was the key temperature for milk proteins after changing the $\mathrm{pH}$ of the milk. This paper provides a theoretical basis for optimizing the processing conditions for goat milk and the applications of goat milk proteins.
\end{abstract}

Key words: pH-heat induction, goat milk protein, structural property, functional property

\section{INTRODUCTION}

Goat milk is widely used in dairy products because it is highly digestible, is hypoallergenic, and has high nutritional value (Lou et al., 2018; Chen et al., 2019a). The lower content of $\alpha_{\mathrm{S}_{1}}$-casein and lactose in goat milk might allow $\beta$-LG and lactose to have better digestion and be less allergenic than cow milk (Bevilacqua et al., 2001; Lara-Villoslada et al., 2004; Chen et al., 2018a).

Received April 25, 2019.

Accepted October 2, 2019.

*Corresponding author: cunfangwang@163.com
Milk protein is the most important nutritional component in goat milk, and is a good standard for evaluating and testing the nutritional quality of dairy products (García et al., 2014; Chen et al., 2018a; Zhu et al., 2018). The protein in goat milk is composed of $70 \%$ water-insoluble casein, $25 \%$ water-soluble whey protein, and $5 \%$ fat-soluble milk fat globule membrane protein (Chen et al., 2019a). In the processing and production of dairy products, the proteins in milk are prone to flocculation and precipitation, which has a serious effect on the quality of goat milk products. Therefore, the changes in goat milk proteins during processing are a very important issue.

The stability of milk protein is determined by its structural properties, and the structural properties are related to the functional properties. The changes in the functional properties of milk proteins during processing are the macroscopic effects of changes in the structural properties. Acidification and heat treatment are commonly used in process milk to dairy products (Montilla and Calvo, 1997; Yuksel et al., 2010; Li et al., 2014), and these processes can rapidly change the spatial structure of proteins and the interactions between proteins, affecting the structural and functional properties of milk proteins (Xu et al., 2015; Lajnaf et al., 2017; Chen et al., 2019b). Previous work has investigated the effects of heat treatment on milk protein functionality at emulsion interfaces, which appear to be important with respect to the physico-chemical properties of milk-protein-stabilized emulsions (Raikos, 2010). Understanding the changes in the structural and functional properties of milk proteins during acidification and heat treatment will facilitate the optimization of the production process and improve the quality of milk products.

The mechanism and the $\mathrm{pH}$ dependence of heatinduced instabilities of the milk protein have been the subject of previous research, most of which has been performed on micellar casein systems of cattle milk (Sauer and Moraru, 2012; Stănciuc et al., 2012; Nair et al., 2013). Some research has also focused on the 
effects of succinylation or other modification mechanisms on the physicochemical and functional properties of proteins (Shilpashree et al., 2015). Previous works have shown the potential of varying the structural and functional properties of milk proteins as affected by disodium phosphate addition, diafiltration, and highpressure homogenization (Meena et al., 2017; Yu et al., 2018). However, a detailed understanding of the changes in the structural and functional properties of goat milk that occur during $\mathrm{pH}$ and heating treatment has not been reported. The objective of this study was to elucidate the effects of $\mathrm{pH}$ and heat treatment on the structural and functional properties of goat milk proteins. In particular, this research focused on the effect of partial acidification of goat milk to $\mathrm{pH} 6.5$ and basification of goat milk to $\mathrm{pH} 7.7$ on proteins during heat processing. It is important to fully understand the effect of the parameter on the structural properties of goat milk proteins and the potential of modifying processing techniques to achieve specific functionalities.

\section{MATERIALS AND METHODS}

\section{Sample Collection and Preparation}

Fresh goat milk samples were collected from Tai'an Three Xi goat farms in Shandong Province, China. This farm raises the goats in freestall barns and feeds a TMR silage diet. Feces are cleared manually, and machine milking is performed at $1000 \mathrm{~h}$. A total of 200 dairy goats at the peak of lactation showing no signs of acute mastitis or other clinical diseases were involved in this study. The milk samples were transported to the laboratory under refrigeration.

All milk samples were centrifuged at $4^{\circ} \mathrm{C}$ and 1,365 $\times g$ for 20 min to remove fat, then were adjusted to $\mathrm{pH}$ levels of $6.5,6.9,7.3$, and 7.7 with $10 \%$ acetic acid or $1 \mathrm{~mol} / \mathrm{L}$ sodium hydroxide solution as necessary. These milk samples were heated at $65,85,105$, and $125^{\circ} \mathrm{C}$ for $15 \mathrm{~s}$, respectively, and served as the treated groups, referring to the study of Chen et al. (2019a). As Figure 1 shows, the fresh goat milk samples were used as the control group (CG).

\section{Determination of the Thermal Stability of Goat Milk Protein}

The thermal stabilities of goat milk the protein treated at different $\mathrm{pH}$ values were evaluated using differential scanning calorimetry, as described by Pugliese et al. (2016) with some modifications. In this study, the flow rate of nitrogen was $60 \mathrm{~mL} / \mathrm{min}$ as a shielding gas and $40 \mathrm{~mL} / \mathrm{min}$ as a reaction gas. The thermal denaturation temperature and enthalpy change $(\Delta \mathrm{H})$ of the protein were analyzed via the peak temperature and peak area using the method described previously.

\section{Determination of the Surface Hydrophobicity of Goat Milk Protein}

Changes in the surface hydrophobicity of the goat milk protein in the treated and control samples were determined by fluorescence probe techniques, as described by Yuksel et al. (2010) with some modifications. The concentration of the 8-anilino-1-naphthalenesulfonic acid (Aladdin, Shanghai, China) fluorescent probe was $8 \mathrm{mmol} / \mathrm{L}$. The fluorescence intensities of the samples were measured by a fluorescence photometer with an excitation wavelength of $380 \mathrm{~nm}$, an emission wavelength of $470 \mathrm{~nm}$, and excitation and emission slit widths of $5 \mathrm{~nm}$.

\section{Determination of the Average Particle Size, Zeta Potential, and Turbidity of Goat Milk Protein}

A $200-\mu \mathrm{L}$ aliquot of sample was diluted to $10 \mathrm{~mL}$ with $0.1 \mathrm{~mol} / \mathrm{L} \mathrm{Na}_{2} \mathrm{HPO}_{4}-\mathrm{NaH}_{2} \mathrm{PO}_{4}(\mathrm{pH}$ 7.0) buffer solution. After mixing thoroughly, the samples were centrifuged at $1,078 \times g$ for $5 \mathrm{~min}$ at room temperature to remove dust and impurities. The particle size of the proteins was determined by a nanometer particle size analyzer according to the method described by Yang et al. (2018). The relative parameters were as follows: measuring temperature $25^{\circ} \mathrm{C}$, scattering angle $90^{\circ}$, particle refractive index 1.450, particle absorptivity 0.8872 , using water as a dispersant, and with a dispersant refractive index of 1.330. Using the method described by O'Brien et al. (1995), the zeta potential of the goat milk samples was determined using a Ma Erwen (Malvern, UK) nanometer particle size analyzer with laser Doppler microelectrophoresis. The turbidity of the goat milk protein samples was determined by spectrophotometry, and the absorbance (A) of each sample was determined using a UV spectrophotometer at room temperature with a maximum absorption wavelength of $633 \mathrm{~nm}$ (Partschefeld et al., 2007).

\section{Determination of the Secondary Structure of Goat Milk Proteins}

The secondary structure of goat milk protein samples was determined by Fourier-transform infrared spectroscopy, as described by El Oudiani et al. (2017). Considering that potassium bromide sample was scanned as background, the sample powder obtained by freezedrying was ground evenly with potassium bromide and 
then pressed into flaking, and the secondary structure was determined by infrared spectrometry. The detection window was 4,000 to $400 \mathrm{~cm}^{-1}$, the spectral resolution was $4 \mathrm{~cm}^{-1}$, and the number of scans was 32 .

\section{Scanning Electron Microscopy of Goat Milk Protein}

A $100 \mu \mathrm{g} / \mathrm{mL}$ solution of goat milk protein was prepared, and $5 \mu \mathrm{L}$ of this solution was dripped on a single silicon wafer, dried, and $50 \mu \mathrm{L}$ of glutaraldehyde fixed solution $(2.5 \%)$ was added. The samples was sealed with fresh-keeping film and fixed at $4^{\circ} \mathrm{C}$ for at least 5 h. The samples were cleaned with $\mathrm{Na}_{2} \mathrm{HPO}_{4}-\mathrm{NaH}_{2} \mathrm{PO}_{4}$ buffer solution, dehydrated in graded ethanol solutions, allowed to dry naturally, and then coated with gold to make them electrically conductive. The samples were observed by an ASU8010 cold-field emission scanning electron microscope as described by Min et al. (2014).

\section{Determination of the Emulsifying Properties of Goat Milk Protein}

The sample solution $(\rho=1 \mathrm{mg} / \mathrm{mL})$ was mixed evenly with soybean oil at a 3:1 ratio and emulsified by a FJ200 high-speed dispersing machine (Biaoben model factory, Shanghai, China) for $1 \mathrm{~min}(10,000$ $\mathrm{rpm})$. Then, $400 \mu \mathrm{L}$ from the bottom of the emulsified sample solution was extracted and diluted with $16 \mathrm{~mL}$ of $0.1 \%$ SDS solution. Finally, the sample solution was measured using an UV spectrophotometer at $500 \mathrm{~nm}$ (Pearce and Kinsella, 1978). The 0.1\% SDS solution was used as a blank to measure the absorbance value, $A_{0}$. The sample solution was allowed to stand for 10 min and then diluted again to determine the absorbance value, $\mathrm{A}_{1}$. The emulsifying activity index (EAI) and emulsion stability (ES) were calculated by the following formula. In the formula, $\mathrm{N}$ is the dilution factor

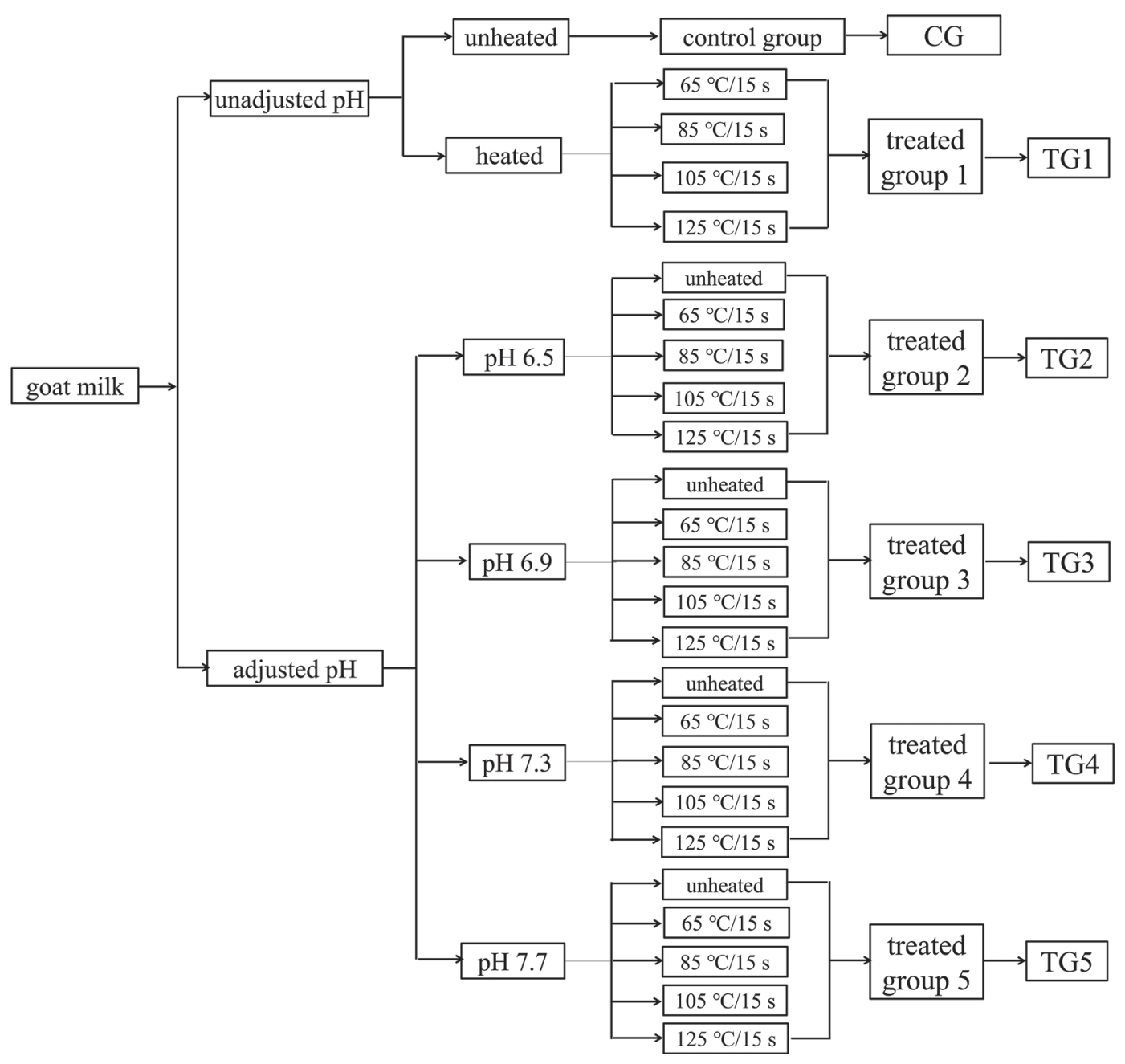

Figure 1. Workflow for sample collection and preparation. $\mathrm{CG}=$ control group; $\mathrm{TG}=$ treated group. 
of the milk protein, $\varphi$ is the volume fraction of the oil phase in the sample emulsion, and $\mathrm{L}$ is the diameter of the colorimetric cup $(\mathrm{cm})$.

$$
\begin{gathered}
\mathrm{EAI}=\left(2 \times 2.303 \mathrm{~A} \times \mathrm{N} \times 10^{-4}\right) /(\varphi \mathrm{L} \rho) ; \\
\operatorname{ES}(\%)=\mathrm{A}_{1} / \mathrm{A}_{0} \times 100 \% .
\end{gathered}
$$

\section{Determination of the Foaming Properties of Goat Milk Protein}

A 3-mL aliquot of sample was transferred with a micropipette into a 10-mL mixing cylinder with a stopper, and it was vigorously oscillated by hand for $1 \mathrm{~min}$ to achieve foaming. The foam height was immediately recorded $(0 \mathrm{~min})$ as the initial foam height, $\mathrm{V}_{0}$. After setting in the measuring cylinder for $30 \mathrm{~min}$, the foam height $\left(\mathrm{V}_{1}\right)$ was recorded again. The ratio of the initial height to the sample content was taken as an indicator of foaming capacity (FC). The ratio of foam height after $30 \mathrm{~min}\left(\mathrm{~V}_{1}\right)$ to the $\mathrm{V}_{0}$ was used as an indicator of foam stability (FS; Meena et al., 2017).

\section{Determination of the Water-Holding Capacity and Oil-Holding Capacity of Goat Milk Proteins}

The protein sample $(\mathrm{m}=0.05 \mathrm{~g})$ was placed into a 2.5-mL Eppendorf tube, and the total mass $\left(\mathrm{m}_{1}\right)$ was determined. Then, $1 \mathrm{~mL}$ of distilled water or $1 \mathrm{~mL}$ of soybean oil was added. After mixing thoroughly, the mixture was allowed to stand for $30 \mathrm{~min}$ and then centrifuged at room temperature at $1,078 \times g$ for 30 min. Finally, the supernatant was removed and the precipitate inverted for $30 \mathrm{~min}$, and the mass of the goat milk protein and the Eppendorf tube was determined again $\left(\mathrm{m}_{2}\right)$. The water-holding capacity (WHC) and the oil-holding capacity $(\mathbf{O H C})$ were calculated by the following formula:

$$
\mathrm{WHC}(\mathrm{OHC})=\left(\mathrm{m}_{2}-\mathrm{m}_{1}\right) / \mathrm{m} .
$$

\section{Data Processing and Analysis}

All the data were recorded and statistically processed using Excel 2016 (Microsoft Corp., Redmond, WA), and Origin 8.0 (OriginLab, Hampton, MA) was used for drawing. The averages, standard deviations, and significance $(P<0.05)$ of experimental data from different combinations of $\mathrm{pH}$ and temperature treatments were calculated and analyzed by IBM SPSS Statistics 23.0 (IBM Corp., Armonk, NY). The experimental results are expressed as means \pm standard deviation.

\section{RESULTS AND DISCUSSION}

\section{Analysis of the Thermal Stability of Goat Milk Protein as Affected by $\mathrm{pH}$ and Heat}

Differential scanning calorimetry can be used to assess the structural changes in samples during the thermal treatment and concomitant performances changes (Ptiček Siročić, 2017). As shown in Figure 2, the $\mathrm{pH}$ had a significant effect on the thermal stability of goat milk proteins $(P<0.05)$. The $\mathrm{pH}$ value of the treated group with $\mathrm{pH} 6.5$ was close to that of the $\mathrm{CG}$, and the denaturation temperature did not change significantly. Among another 3 treated groups with $\mathrm{pH}$ 6.9, 7.3, and 7.7, the thermal denaturation temperature of the goat milk proteins decreased gradually with the increasing of $\mathrm{pH}$ value. The thermal denaturation temperature of the goat milk protein at $\mathrm{pH} 7.7$ was significantly lower than that of CG $(P<0.05)$. The results showed a lower thermal stability for the treated groups with $\mathrm{pH} 6.9$, 7.3, and 7.7 compared with CG. This may be explained by the lower protein stability due to the higher intramolecular repulsion of the deprotonated groups in the protein. On the other hand, the reactivity of the free thiol groups is expected to increase with increasing $\mathrm{pH}$ (Leeb et al., 2018). Higher reactivity of the thiol groups might enhance intermolecular thiol-disulfide exchange reactions and a subsequent irreversible denaturation of the protein (Hoffmann and Van Mil, 1999).

\section{Surface Hydrophobicity Analysis of Goat Milk Protein as Affected by $\mathrm{pH}$ and Heat}

As shown in Figure 3A, the surface hydrophobicity of the goat milk protein treated at $85^{\circ} \mathrm{C}$ and above was significantly greater $(P<0.05)$ than that of the $\mathrm{CG}$ and reached maximum at $85^{\circ} \mathrm{C}$, indicating that the hydrophobic groups exposed on the surface of the milk protein increased when the heating temperature was increased to $85^{\circ} \mathrm{C}$. This may be explained by the fact that when the temperature was lower than $85^{\circ} \mathrm{C}$, the heating caused exposure of the thiol group, the whey protein conformation changes and the protein structure unfolds, resulting in the exposure of the hydrophobic site, and thus the surface hydrophobicity is increased (Vasbinder and de Kruif, 2003; Choudhary et al., 2018). With increasing heating temperature $\left(85-125^{\circ} \mathrm{C}\right)$, interaction between $\beta$-LG and cysteine containing whey protein such as $\alpha$-LA led to the formation of whey protein aggregates, and $\beta-\mathrm{LG}$ and $\mathrm{K}$-casein formed casein-whey protein aggregation by thiol-disulfide bond exchange reactions, which resulted in irregular surface structures of the casein and improvements in surface hydrophobic- 


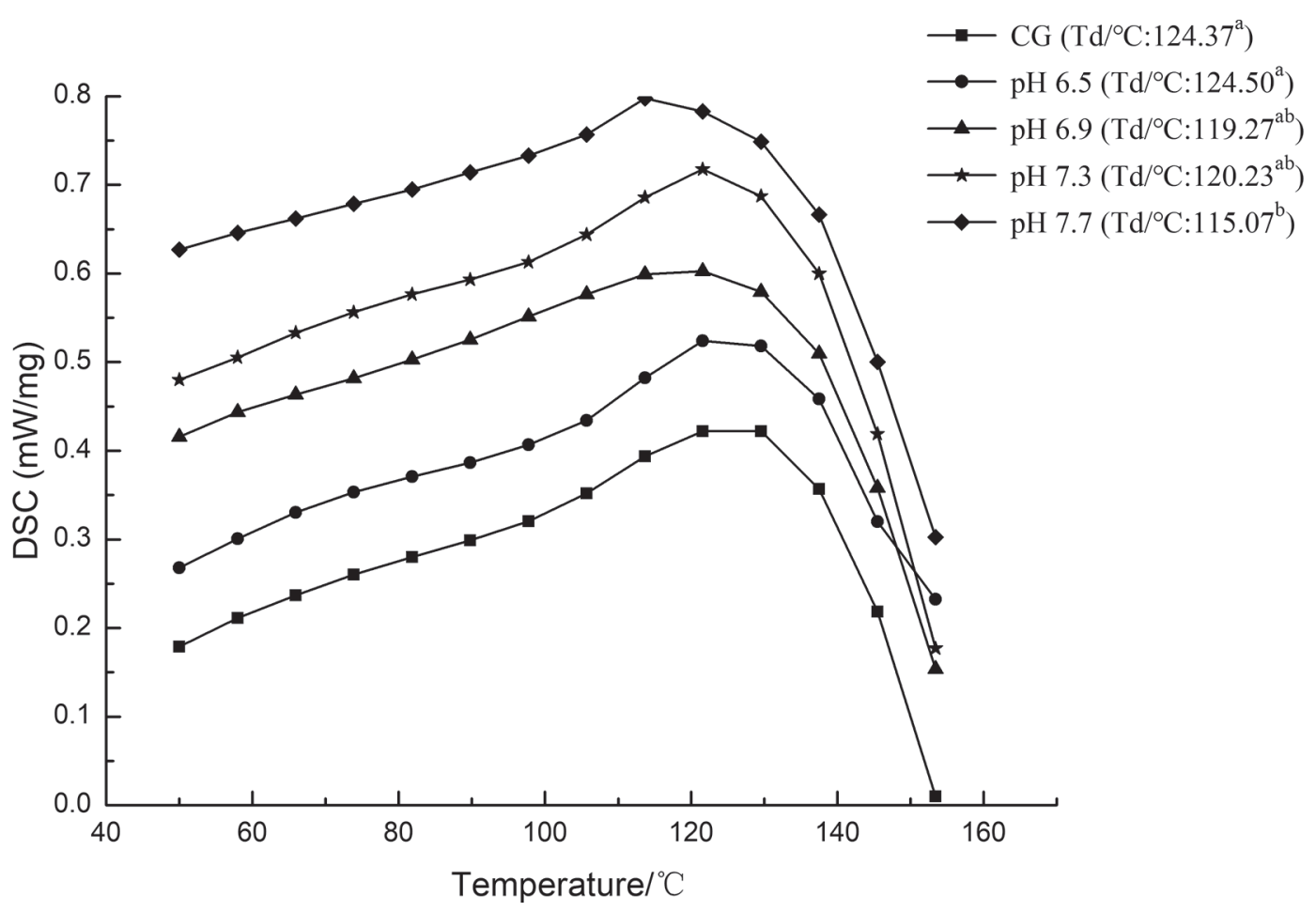

Figure 2. Differential scanning calorimetry (DSC) curves of goat milk proteins as affected by pH and heat. CG = control group. Values of each group not sharing the same letters are significantly different $(P<0.05)$.

ity (Vasbinder and de Kruif, 2003; Choudhary et al., 2018). However, the polymerization between proteins caused hydrophobic groups to be embedded in the polymer. In addition, denatured $\beta$-LG combined with $\alpha$-LA such that the surface irregularities of the casein were filled, and the surface became smooth, resulting in a decrease in hydrophobicity (Michel et al., 1997).

As seen from Figure 3B, with the exception of $\mathrm{pH}$ 7.7, the surface hydrophobicities of the goat milk protein at different $\mathrm{pH}$ levels were significantly lower than that of fresh milk $(P<0.05)$, which indicated that changing the $\mathrm{pH}$ could change the hydrophobicity of goat milk proteins. The surface hydrophobicities of goat milk proteins at different $\mathrm{pH}$ conditions were significantly affected by the temperature used during heat treatment $(P<0.05)$, and the trend was generally consistent with fresh milk (Figure 3A). The surface hydrophobicity of goat milk protein at $\mathrm{pH} 6.9$ reached its maximum at $105^{\circ} \mathrm{C}$, whereas at other $\mathrm{pH}$ values, the maximum was observed at $85^{\circ} \mathrm{C}$, indicating that
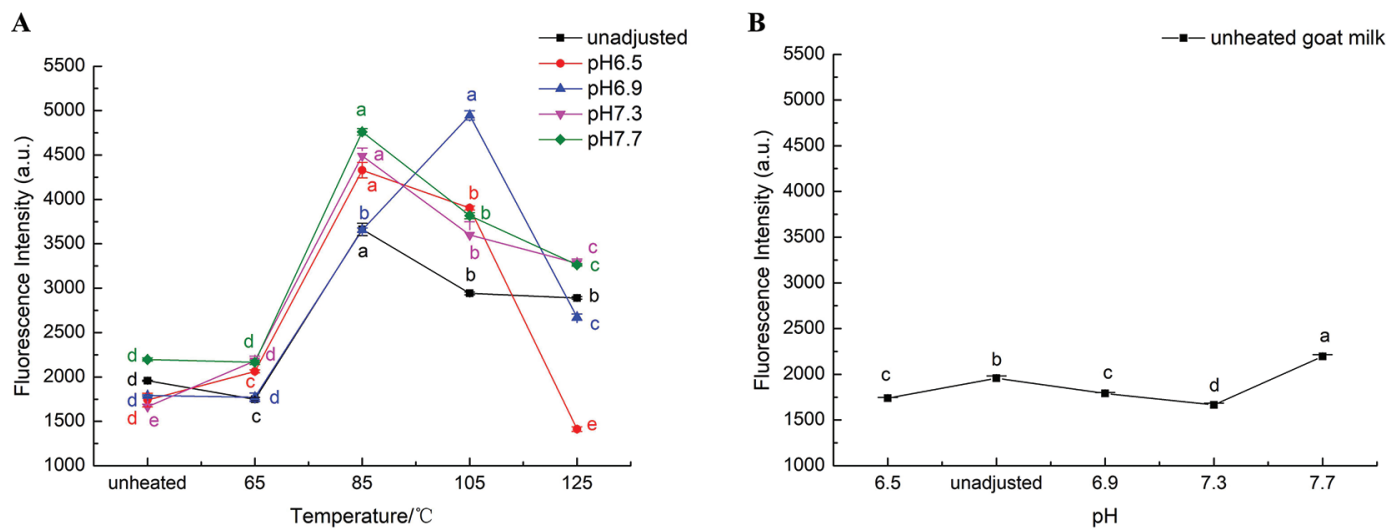

Figure 3. Changes induced by $\mathrm{pH}$ and heat on the surface hydrophobicity of goat milk proteins. Values of each group not sharing the same letters $(\mathrm{a}-\mathrm{e})$ are significantly different $(P<0.05)$, and error bars represent SD. 
$\mathrm{pH}$ can change the characteristics of the hydrophobic groups in the goat milk proteins during heating. Jean et al. (2006) suggested that the surface hydrophobicity of casein and whey protein aggregates produced during treatment at high temperatures were very high under neutral $\mathrm{pH}$ conditions, which was similar to the results of the current study. It was found that ionic calcium, $\mathrm{pH}$, and total soluble divalent cations decreased as temperature increased between 20 and $110^{\circ} \mathrm{C}$ in both dialysates and ultrafiltration permeates (On-Nom et al., 2010). In addition, the change in $\mathrm{pH}$ leads to the different conformations in the goat milk proteins and the distribution of hydrophobic groups inside and outside of the molecule, resulting in a change in the surface hydrophobicity of the goat milk protein during heating (Lam and Nickerson, 2015).

\section{Analysis of the Particle Size, Zeta Potential, and Turbidity of Goat Milk Protein as Affected by $\mathrm{pH}$ and Heat}

As shown in Figure 4A and 4C, compared with those of $\mathrm{CG}$, the goat milk protein samples treated at different temperatures had significantly different particle sizes and zeta potentials $(P<0.05)$. The average particle size and zeta potential initially decreased and then increased with increasing treatment temperature. However, Figure 4B showed the particle size of goat milk protein was not significantly affected by $\mathrm{pH}(P>0.05)$. Figure $4 \mathrm{~A}$ and $4 \mathrm{C}$ show that the particle size and zeta potential of goat milk protein treated at different $\mathrm{pH}$ values decreased significantly at $85^{\circ} \mathrm{C}(P<0.05)$, which indicated that $85^{\circ} \mathrm{C}$ was the key point of the change for the goat milk protein after $\mathrm{pH}$ adjustment. When the heated temperature is less than $85^{\circ} \mathrm{C}$, whey protein denatured and dissociated from oligomer to monomer, casein micelle depolymerized, $\mathrm{K}$-casein dissociated on micelle surface, and the degree of dissociation increased with increasing temperature. The micelle morphology was broken and became loose, resulting in a decrease in particle size, an increase in the net negative surface charge, and a decrease in the zeta potential (Alexander et al., 2002). When the heated temperature is higher than $85^{\circ} \mathrm{C}$, whey protein monomers formed polymers through disulfide bonds, and $\beta-\mathrm{LG}$ and $\mathrm{K}$-casein formed casein-whey protein aggregation by thiol-disulfide bond exchange reactions. The aggregation of casein itself and the binding of casein to whey protein were higher than the degree of depolymerization of casein itself, resulting in an increase in protein particle size (del Angel and Dalgleish, 2006; Lin et al., 2018).

In addition, the change of trend in the particle sizes of goat milk protein at $\mathrm{pH} 6.5$ and 7.7 after heat treatment were basically the same as those of fresh goat milk (Figure 4A). When the $\mathrm{pH}$ was 6.9 , the smallest goat milk protein particle size was observed at $85^{\circ} \mathrm{C}$ and the largest was at $105^{\circ} \mathrm{C}$. At $\mathrm{pH} 7.3$, the average goat milk protein particle size gradually decreased with increasing temperature. It can be hypothesized that near neutral $\mathrm{pH}, \beta-\mathrm{LG}$ oligomers depolymerized into monomers and reacted more easily with other proteins during heat treatment. Previous research has also demonstrated that changes in $\mathrm{pH}$ before heating affect the formation and composition of goat milk protein aggregates during heat treatment (Vasbinder and de Kruif, 2003; Nair et al., 2013).

As shown in Figure $5 \mathrm{~A}$, above $85^{\circ} \mathrm{C}$, the turbidity of the goat milk protein was significantly higher than that of the CG $(P<0.05)$, indicating that heat treatment can result in the denaturation of the goat milk proteins to varying degrees. With the exception of $\mathrm{pH} 7.7$, the turbidity of goat milk protein at various $\mathrm{pH}$ values increased significantly with increasing temperature $(P<$ $0.05)$. The trend in the turbidity found in this study was similar to that of Anema and Klostermeyer (1997). The diameter and light scattering coefficient of the milk protein particles changed, and the milk proteins were dissociated and aggregated to different degrees. As shown in Figure 5B, pH had a significant effect on the turbidity of the goat milk proteins $(P<0.05)$. In addition, the turbidity of the goat milk proteins under basic conditions ( $\mathrm{pH} 7.3$ and 7.7) was lower than under acidic conditions ( $\mathrm{pH} 6.5$ and 6.9) during heat processing (Figure 5A). These results showed that changes in $\mathrm{pH}$ caused changes in the thermal induction of goat milk protein. Lower $\mathrm{pH}$ values resulted in greater degrees of milk protein aggregation. At a lower $\mathrm{pH}$, the whey protein/casein polymer formed on the micelle surface when the whey protein and casein micelle interacted with each other during heat treatment, which resulted in an increase in turbidity. At higher $\mathrm{pH}$ values, the proteins interact to form soluble whey protein/ $\kappa$-casein complexes, which mainly exist in the whey phase and result in decreased turbidity (Vasbinder and de Kruif, 2003; Vasbinder et al., 2004; Nair et al., 2013).

\section{Structural Analysis of Goat Milk Protein as Affected by $\mathrm{pH}$ and Heat}

Fourier-Transform Infrared Spectroscopy of Goat Milk Protein as Affected by $p H$ and Heat. As shown in Figure 6, the infrared spectra of the treated samples were similar to that of the CG, and the characteristic absorption peaks at 1,700 to $1,600 \mathrm{~cm}^{-1}$ exhibited obvious redshifts and blueshifts. The 1,700 to 1,600 $\mathrm{cm}^{-1}$ band is the most commonly used amide I band for protein analysis, as it is characteristic of the vibrational stretching of $\mathrm{C}=\mathrm{O}$ moieties in the protein (Morand et 
A
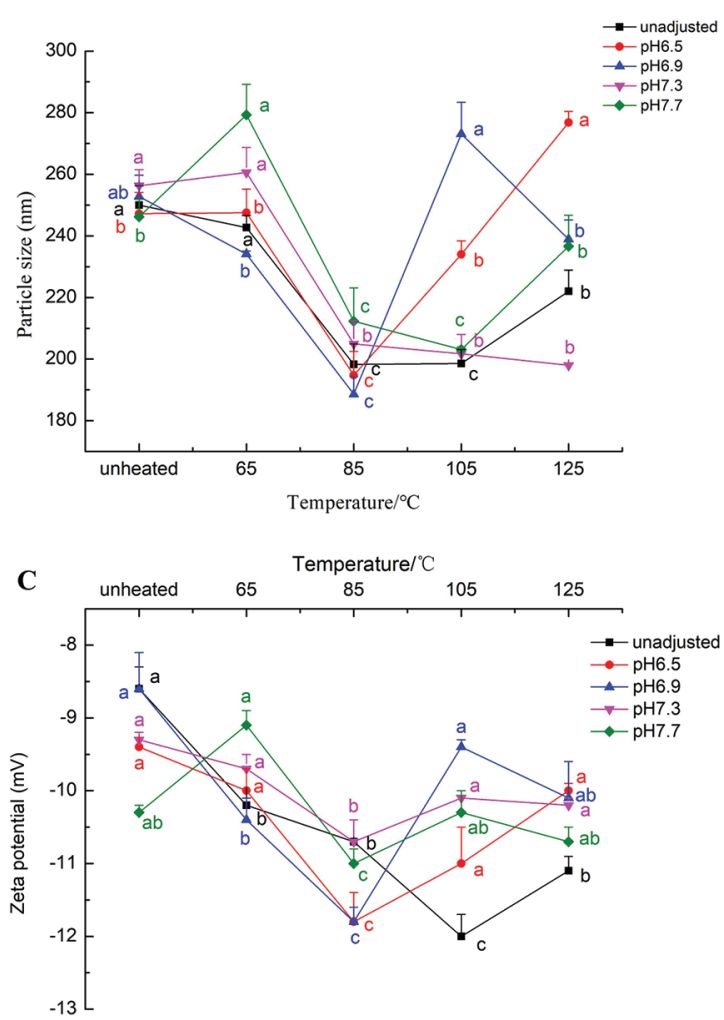

B

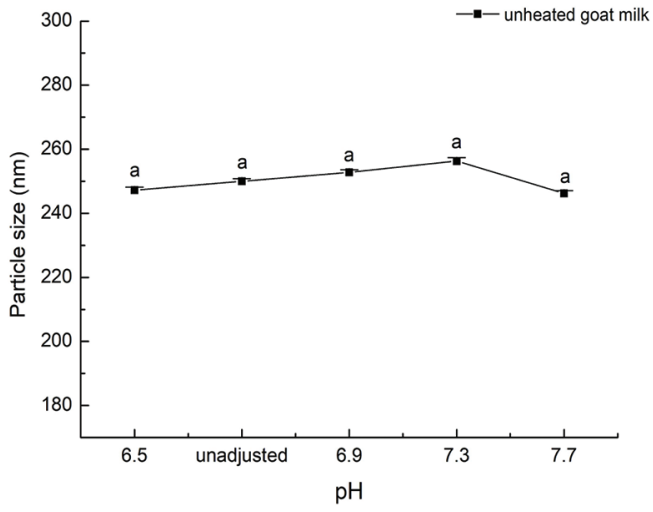

D

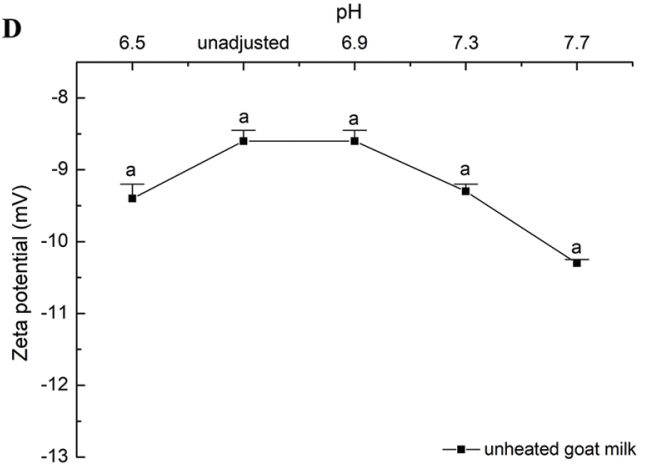

Figure 4. Changes induced by $\mathrm{pH}$ and heat on the particle size and zeta potential of goat milk proteins. Values of each group not sharing the same letters $(\mathrm{a}-\mathrm{c})$ are significantly different $(P<0.05)$, and error bars represent SD.

al., 2011). Compared with the CG, the 1,700 to 1,600 $\mathrm{cm}^{-1}$ absorption band of goat milk protein at $\mathrm{pH} 6.9$ showed a significant redshift, indicating that $\mathrm{pH}$ had a significant effect on the secondary structure of goat milk protein (Figure 6B). The absorption peaks of $\mathrm{pH}$ 6.5 and 6.9 goat milk treated at $105^{\circ} \mathrm{C}$ were observed at $1,649.9$ and $1,654.1 \mathrm{~cm}^{-1}$, respectively, correspond- ing to a significant redshift (Figure 6C and 6G). The results indicated that milk protein was unstable to $\mathrm{pH}$ and heat cotreatment. When the AA residues formed intermolecular hydrogen bonds, the electron density on the $\mathrm{C}=\mathrm{O}$ moieties decreased, and the absorption peak shifted toward lower wavenumbers (Jackson and Mantsch, 1995). For $105^{\circ} \mathrm{C}$ treated samples, the absorption

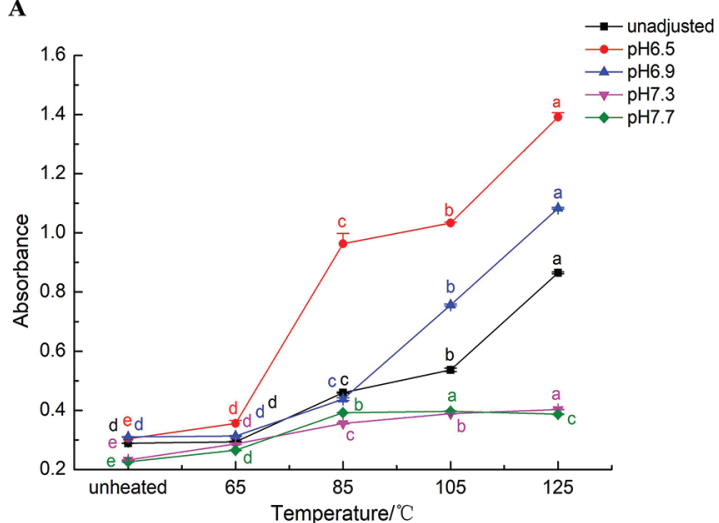

B

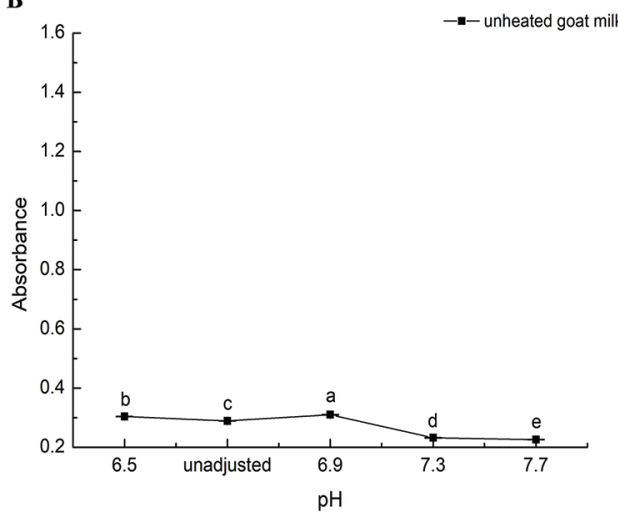

Figure 5. Changes induced by $\mathrm{pH}$ and heat on the turbidity of goat milk proteins. OD = optical density. Values of each group not sharing the same letters $(\mathrm{a}-\mathrm{e})$ are significantly different $(P<0.05)$, and error bars represent SD. 

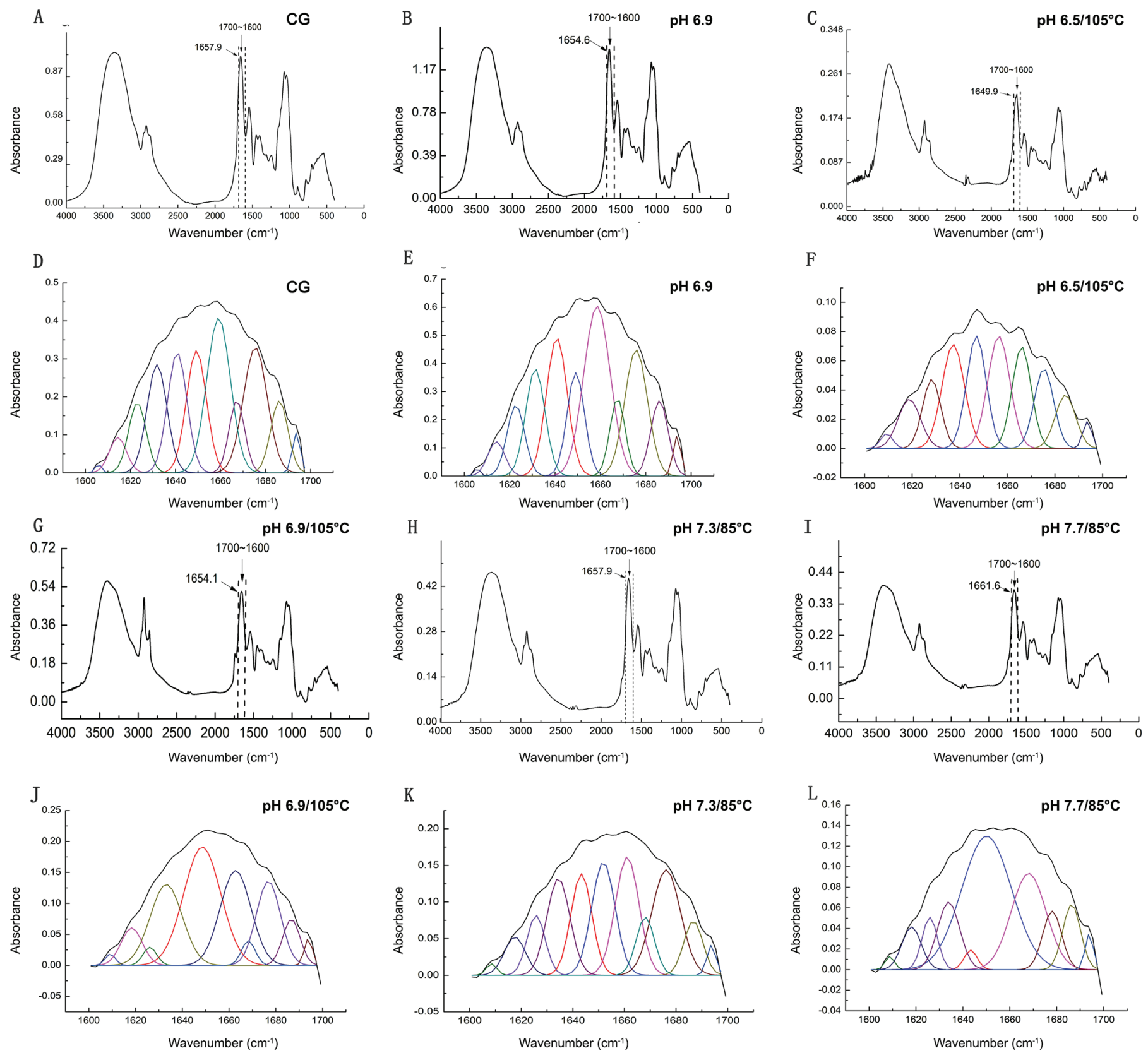

Figure 6. Fourier-transform infrared spectra of goat milk proteins as affected by $\mathrm{pH}$ and heat. $\mathrm{CG}=$ control group.

peaks of the goat milk protein samples treated at $\mathrm{pH} 6.5$ and 6.9 were 1.649 .9 and $1.654 .1 \mathrm{~cm}^{-1}$ (Figure $6 \mathrm{C}$ and $6 \mathrm{G}$ ), whereas for $85^{\circ} \mathrm{C}$, the samples at $\mathrm{pH} 7.3$ and 7.7 were observed at $1,657.9$ and $1,661.6 \mathrm{~cm}^{-1}$, respectively, corresponding to a significant blueshift (Figure $6 \mathrm{H}$ and $6 \mathrm{I})$. Thus, we can see that the different $\mathrm{pH}$ treatments and temperatures influenced the conformations of the proteins, as they disrupted the intramolecular hydrogen bonds, causing the peaks to shift toward higher wavenumbers (Barreto et al., 2003).
Fitting of the Amide I Bands of Goat Milk Protein as Affected by $p H$ and Heat. The number and position of characteristic peaks can be determined from the second derivative of the amide band I, and the deconvolution and multipeak fitting operations were carried out by peak fit (Figure 6D, 6E, 6F, 6J, 6K, and $6 \mathrm{~L})$. The secondary structures of the protein include regular $\alpha$-helix $\left(1,650-1,660 \mathrm{~cm}^{-1}\right), \beta$-sheet $(1,600-1,640$ $\mathrm{cm}^{-1}$ and $\left.1,682-1,700 \mathrm{~cm}^{-1}\right)$, and $\beta$-turn $(1,661-1,681$ $\mathrm{cm}^{-1}$ ) structures, and the irregular structures include 
an irregular curl $\left(1,641-1,650 \mathrm{~cm}^{-1}\right)$. According to the relationship between the secondary structure and the subpeak in the amide I band, the relative contents of the secondary structures in all samples were calculated based on the integrals (Table 1 ).

The secondary structure in the CG was mainly $\beta$-sheets, accounting for $34.45 \%$ of the total, but the percent of regular structures in the $\mathrm{pH}$ treated and unheated groups decreased to varying degrees, and it was the lowest at $\mathrm{pH} 6.9$, and the content of $\alpha$-helix at $\mathrm{pH}$ 6.9 was significantly reduced compared with the CG. The acidic environment may increase the electrostatic interactions among proteins due to neutralization of the charge, affecting the stability of the hydrogen bonds and reducing the content of the $\alpha$-helices (Fennema, 1996; Damodaran, 2008). The changes in electrostatic interactions and hydrogen bond stability could in turn contribute to the loss of a-helix content under acidic conditions (Liu et al., 2008). When goat milk samples at different $\mathrm{pH}$ levels were heated, the content of irregular structures in the milk proteins were observed the trend of declining and then increasing. The $\mathrm{pH}$ value of solution is a very important factor affecting the formation or stability of a-helix structure. Where acidic or alkaline AA accumulate, the same charge repulsion on side chains will cause a-helix instability. The mecha- nism of the interaction of $\mathrm{pH}$ and temperature on the stability of a-helix structure is still unclear. However, it can be seen that $\mathrm{pH}$ and heat cotreatment changed the secondary structure of goat milk proteins from ordered to disordered, which resulted in a decrease in their stability to varying degrees. At $\mathrm{pH} 6.5$ and 6.9, the content of regular structures, particularly $\alpha$-helix, decreased upon heating to $105^{\circ} \mathrm{C}$. It has been previously reported that the $\alpha$-helix structures of protein molecules are negatively correlated with hydrophobicity (Kato et al., 1981). When the $\alpha$-helix content decreases, the exposure of hydrophobic moieties embedded in the molecules increases, resulting in stronger surface hydrophobicity, which corresponds to the hydrophobicity results in this study. In addition, for milk at $\mathrm{pH} 7.3$ and 7.7 , the content of regular structures, especially $\beta$-turns, decreased dramatically when heated to $85^{\circ} \mathrm{C}$. It could be concluded that alkaline treatment could decrease the contents of $\alpha$-helix and $\beta$-sheet structures, whereas heat treatment formed thermal aggregates; the $\beta$-sheets between molecules were easily transformed into $\beta$-turns, and a portion of the $\beta$-turns were converted into irregular structures, which lead to a decrease in the $\beta$-turn content and an increase in the irregular structures. These results are in agreement with previous findings by Liu et al. (2008).

Table 1. The secondary structure contents of goat milk proteins as affected by $\mathrm{pH}$ and heat (\%); values shown as means $\pm \mathrm{SD}$

\begin{tabular}{|c|c|c|c|c|c|c|}
\hline$\frac{\text { Group }^{1}}{\text { CG }}$ & \multicolumn{2}{|c|}{ Treatment method } & $\frac{\alpha \text {-Helix }}{32.23 \pm 1.44^{\mathrm{a}}}$ & $\frac{\beta \text {-Sheet }}{34.45 \pm 3.62^{\mathrm{a}}}$ & $\frac{\beta \text {-Turn }}{20.02 \pm 2.65^{\mathrm{ab}}}$ & $\begin{array}{c}\text { Irregular curl } \\
13.29 \pm 0.47^{\mathrm{b}}\end{array}$ \\
\hline TG1 & Unadjusted $\mathrm{pH}$ & $65^{\circ} \mathrm{C}$ & $33.24 \pm 0.16^{\mathrm{a}}$ & $27.89 \pm 0.13^{\mathrm{b}}$ & $22.75 \pm 0.13^{\mathrm{a}}$ & $16.12 \pm 0.13^{\mathrm{a}}$ \\
\hline & & $85^{\circ} \mathrm{C}$ & $32.95 \pm 0.54^{\mathrm{a}}$ & $28.97 \pm 0.61^{\mathrm{b}}$ & $21.67 \pm 0.04^{\mathrm{a}}$ & $16.40 \pm 1.11^{\mathrm{a}}$ \\
\hline & & $125^{\circ} \mathrm{C}$ & $32.99 \pm 0.45^{\mathrm{a}}$ & $30.38 \pm 1.05^{\mathrm{b}}$ & $22.61 \pm 1.30^{\mathrm{a}}$ & $14.02 \pm 0.20^{\mathrm{b}}$ \\
\hline \multirow[t]{2}{*}{ TG2 } & pH 6.5 & Unheated & $27.04 \pm 2.80^{\mathrm{ab}}$ & $35.70 \pm 3.98^{\mathrm{a}}$ & $17.58 \pm 0.25^{\mathrm{ab}}$ & $19.67 \pm 6.53^{\mathrm{b}}$ \\
\hline & & $65^{\circ} \mathrm{C}$ & $31.72 \pm 0.42^{\mathrm{a}}$ & $30.20 \pm 0.69^{b}$ & $23.20 \pm 0.69^{\mathrm{a}}$ & $14.87 \pm 1.80^{\mathrm{c}}$ \\
\hline \multirow[t]{5}{*}{ TG3 } & pH 6.9 & Unheated & $24.57 \pm 3.73^{\mathrm{b}}$ & $25.13 \pm 3.85^{\mathrm{b}}$ & $14.26 \pm 5.18^{\mathrm{b}}$ & $36.04 \pm 5.06^{\mathrm{a}}$ \\
\hline & & $65^{\circ} \mathrm{C}$ & $21.91 \pm 10.01^{\mathrm{ab}}$ & $31.82 \pm 1.87^{\mathrm{a}}$ & $21.60 \pm 0.89^{\mathrm{b}}$ & $24.67 \pm 9.04^{\mathrm{ab}}$ \\
\hline & & $85^{\circ} \mathrm{C}$ & $20.07 \pm 0.05^{\mathrm{ab}}$ & $31.23 \pm 0.24^{\mathrm{a}}$ & $21.94 \pm 0.01^{\mathrm{b}}$ & $26.77 \pm 0.29^{\mathrm{ab}}$ \\
\hline & & $105^{\circ} \mathrm{C}$ & $15.92 \pm 4.29^{\mathrm{b}}$ & $32.03 \pm 1.76^{\mathrm{a}}$ & $16.98 \pm 0.60^{\mathrm{a}}$ & $35.45 \pm 5.06^{\mathrm{a}}$ \\
\hline & & $125^{\circ} \mathrm{C}$ & $25.32 \pm 7.68^{\mathrm{ab}}$ & $28.69 \pm 4.99^{\mathrm{a}}$ & $21.54 \pm 0.62^{\mathrm{b}}$ & $24.45 \pm 2.07^{\mathrm{ab}}$ \\
\hline TG4 & $\mathrm{pH} 7.3$ & Unheated & $28.10 \pm 2.90^{\mathrm{ab}}$ & $36.10 \pm 4.58^{\mathrm{a}}$ & $23.72 \pm 0.49^{\mathrm{a}}$ & $12.07 \pm 2.17^{\mathrm{b}}$ \\
\hline \multirow{4}{*}{ TG5 } & & $65^{\circ} \mathrm{C}$ & $16.06 \pm 2.99^{\mathrm{c}}$ & $29.15 \pm 1.88^{\mathrm{b}}$ & $29.46 \pm 4.93^{\mathrm{a}}$ & $25.32 \pm 3.82^{\mathrm{b}}$ \\
\hline & & $85^{\circ} \mathrm{C}$ & $21.01 \pm 0.09^{\mathrm{b}}$ & $28.96 \pm 0.28^{\mathrm{b}}$ & $6.91 \pm 0.01^{\mathrm{c}}$ & $43.12 \pm 0.18^{\mathrm{a}}$ \\
\hline & & $105^{\circ} \mathrm{C}$ & $34.42 \pm 2.58^{\mathrm{a}}$ & $31.12 \pm 2.27^{\mathrm{ab}}$ & $19.34 \pm 0.70^{\mathrm{b}}$ & $15.11 \pm 5.56^{\mathrm{c}}$ \\
\hline & & $125^{\circ} \mathrm{C}$ & $22.51 \pm 0.01^{\mathrm{b}}$ & $33.66 \pm 0.10^{\mathrm{a}}$ & $19.89 \pm 0.06^{\mathrm{b}}$ & $23.93 \pm 0.05^{\mathrm{b}}$ \\
\hline
\end{tabular}

${ }^{\mathrm{a}-\mathrm{d}}$ Different letters indicate a significant difference $(P<0.05)$ among different $\mathrm{pH}$ and heat treatment groups.

${ }^{1} \mathrm{CG}=$ control group; $\mathrm{TG}=$ treated group. 


\section{Analysis of the Surface Structure of Goat Milk Protein as Affected by $\mathrm{pH}$ and Heat}

As shown in Figure 7A, the scanning electron microscopy results showed that the fresh goat milk proteins were spherical, smooth, fine particles. Figure 7B suggested that the size, distribution, and surface morphology of the goat milk proteins heated at $65^{\circ} \mathrm{C} / 15 \mathrm{~s}$ were uniform and regular, and the particle size of the micelles clearly decreased compared with Figure 7A. The size difference might be resulted by the structural rearrangement or shielding of charge. After heat treatment at $125^{\circ} \mathrm{C} / 15 \mathrm{~s}$, due to the increased heating temperature, the interactions among the proteins caused aggregation, and the protein particles were partially agglomerated. Compared with Figure 7A, the particle size was obviously increased, the proteins had an irregular shape, and a dense network structure was observed in Figure 7C. At pH 6.5, the surface morphology appeared to be similar to that of the original spherical micellar morphology, which was conducive to the stability of the micelles (Figure 7D). Compared with the CG, the surface of the milk protein particles was not smooth, but the distribution of the particles was more uniform. At $\mathrm{pH}$ 6.9, most of the milk protein particles were spherical. However, the smoothness of the milk protein particles was reduced, the molecular spacing was obviously small, and the distribution of the milk protein particles was uneven (Figure 7E). At pH 7.3, the milk protein molecules showed slight adhesion, and a small number of milk protein particles were connected to each other to form small micelles. These micelles were connected to each other, forming a small number of relatively dense network structures (Figure 7F). At pH 7.7, a large number of dense network structures were formed by interconnection of micelles (Figure 7G). The scanning electron microscopy results indicated that as the $\mathrm{pH}$ of the milk increased, the milk protein became less stable, which was consistent with the differential scanning calorimetry results in this study.

\section{Analysis of the Functional Properties of Goat Milk Protein as Affected by $\mathrm{pH}$ and Heat}

As shown in Figure 8A, a significant difference was observed in the EAI of goat milk proteins between $\mathrm{pH}$ 6.5 and 7.3, which may be related to the hydrophobicity of the surface of the goat milk proteins (PachecoAguilar et al., 2008). According to Figure 8B, the EAI values of goat milk proteins at $\mathrm{pH} 6.5$ and 7.7 were significantly affected by temperature $(P<0.05)$, and the changes in the other groups were not significant $(P$ $>0.05$ ). The milk protein at $\mathrm{pH} 6.5$ had the highest EAI under different treatment conditions except $85^{\circ} \mathrm{C}$.
It can be concluded that $\mathrm{pH} 6.5$ provided the greatest EAI for the goat milk protein. Wagner and Gueguen (1999) also suggested that using an acidic $\mathrm{pH}$ could expand the protein structure, expose hydrophobic groups, increase the hydrophobicity of the surface, and increase the EAI, which was consistent with the results of the present study. According to Figure 8C, the ES values of the treated groups were significantly affected by temperature $(P<0.05)$. The EAI and ES change trend of goat milk proteins with different $\mathrm{pH}$ values were inversely proportional to each other following different heat treatments.
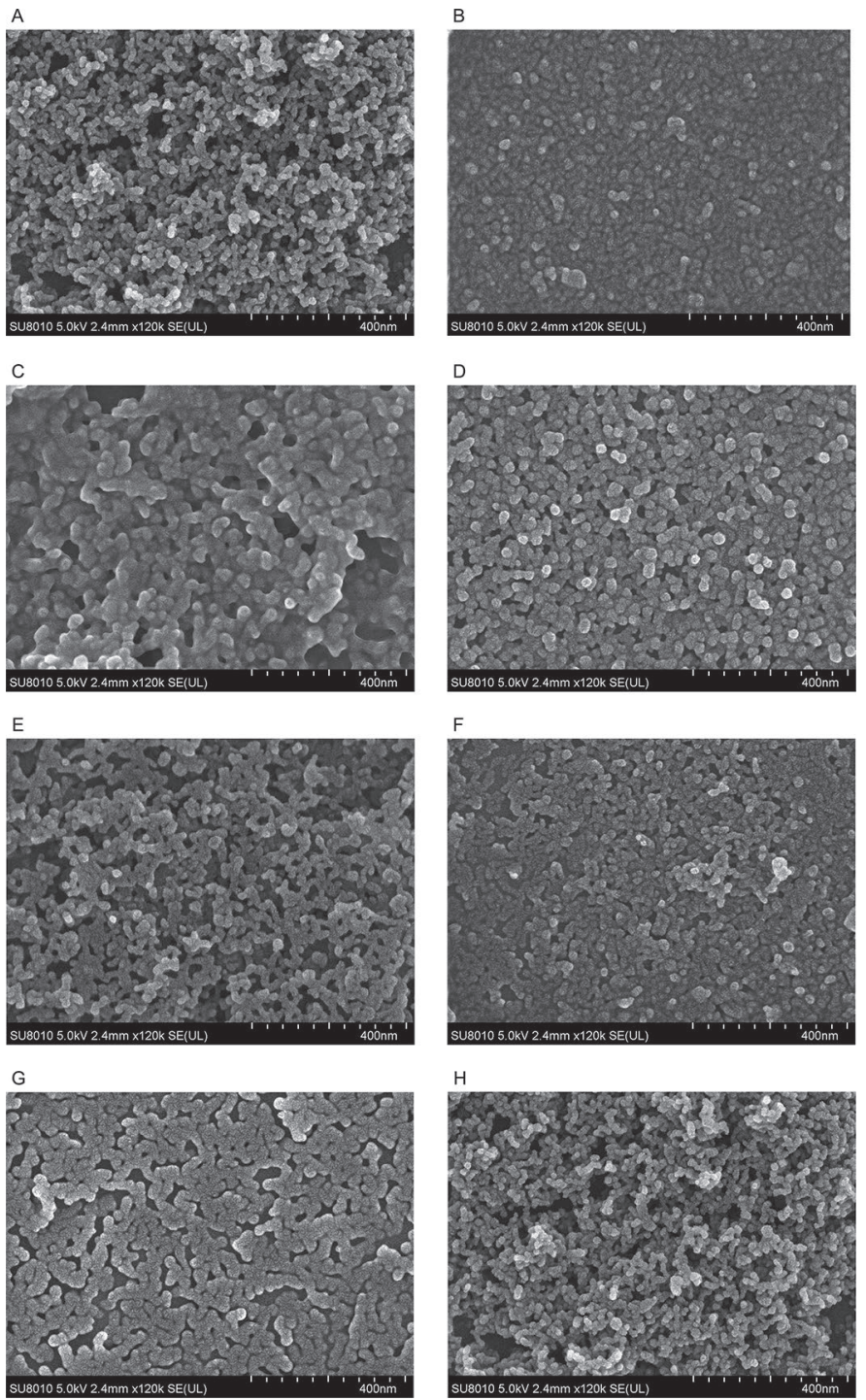

Figure 7. Scanning electron micrographs of goat milk proteins as affected by $\mathrm{pH}$ and heat $(\times 12,000)$. A and $\mathrm{H}$ denote the control group. $\mathrm{B}$ and $\mathrm{C}$ denote the samples heated at $65^{\circ} \mathrm{C}$ for $15 \mathrm{~s}$ and $125^{\circ} \mathrm{C}$ for 15 s, respectively. D, E, F, and $\mathrm{G}$ denote the sample with $\mathrm{pH} 6.5,6.9,7.3$, and 7.7 , respectively. 
As displayed in Figure 9A, the FC of the goat milk proteins treated at $85^{\circ} \mathrm{C}$ and above were significantly lower than that of the $\mathrm{CG}(P<0.05)$, and the $\mathrm{FC}$ also changed significantly at $\mathrm{pH} 6.9$ (Figure 9B). With the exception of $\mathrm{pH} 7.3$, the $\mathrm{FC}$ values of the treated groups and the $\mathrm{CG}$ followed the same trends with increasing temperature. Compared with the unheated and $65^{\circ} \mathrm{C}$ treatment groups, when the temperature was above $85^{\circ} \mathrm{C}$, significant differences were present (Figure 9A). A previous study showed that heat treatment below $85^{\circ} \mathrm{C}$ increased the $\mathrm{FC}$ of proteins, whereas heat treatments above $85^{\circ} \mathrm{C}$ reduced the $\mathrm{FC}$, which was consistent with the conclusions of this study (Lajnaf et al., 2018). In addition, changes in the $\mathrm{pH}$ changed the ionization of the proteins, the distribution of hydrophobic groups in the solution, the protein structure, the adsorption at the gas-liquid interface, and the FC (Shan et al., 2012). The FS values of goat milk proteins at $\mathrm{pH} 6.9$ and 7.3 were significantly affected by temperature $(P$ $<0.05$ ), and the trends were entirely different (Figure $10 \mathrm{~A})$. As shown in Figure 9B and 10B, the FC and FS values of $\mathrm{CG}$ were inversely proportional, whereas the milk proteins at $\mathrm{pH} 6.5$ had better $\mathrm{FC}$ and FS values than those of other $\mathrm{pH}$-treated groups, which indicated that changes in the $\mathrm{pH}$ could improve the foaming properties of goat milk proteins at different temperatures (Figure 9A and 10A). Thus, compared with other $\mathrm{pH}$ treatment groups, under slightly acidic conditions, such as $\mathrm{pH} 6.5$, goat milk proteins not only have good foaming abilities but also good FS when heat treated at different temperatures.

From Figure 11A, the WHC was lower under weakly alkaline conditions and higher under acidic conditions, indicating that weak acidity resulted in goat milk protein with a better WHC. The trend in the WHC in this study was similar to that of Chen et al. (2018b). The WHC of goat milk proteins at different $\mathrm{pH}$ values were significantly affected by temperature $(P<0.05)$, and the trends were different (Figure 11B). The WHC of goat milk protein at $\mathrm{pH} 6.5$ and 6.9 were significantly higher than those of the samples at $\mathrm{pH} 7.3$ and 7.7 during heat treatment, especially the $\mathrm{WHC}$ of $\mathrm{pH}$ 6.5 goat milk protein, which was the highest at $85^{\circ} \mathrm{C}$ (Figure 11B). This result showed that acidic conditions were optimal for the WHC of goat milk proteins during heat processing. The $\mathrm{pH}$ influenced the degree of dissociation of the protein molecules, the surface charge, and the interactions among proteins and the change of
A

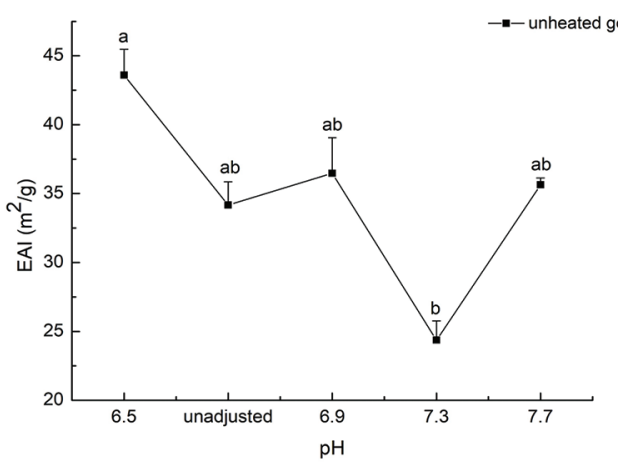

C

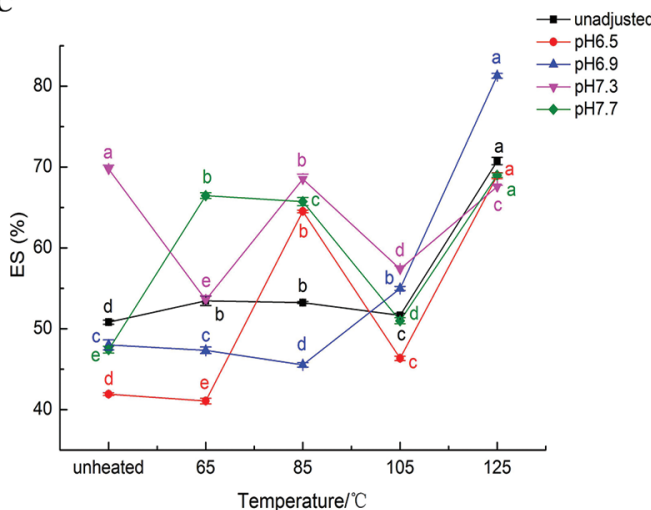

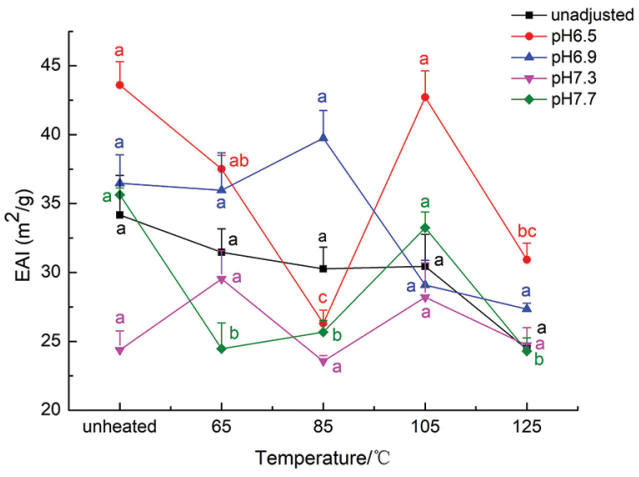

D

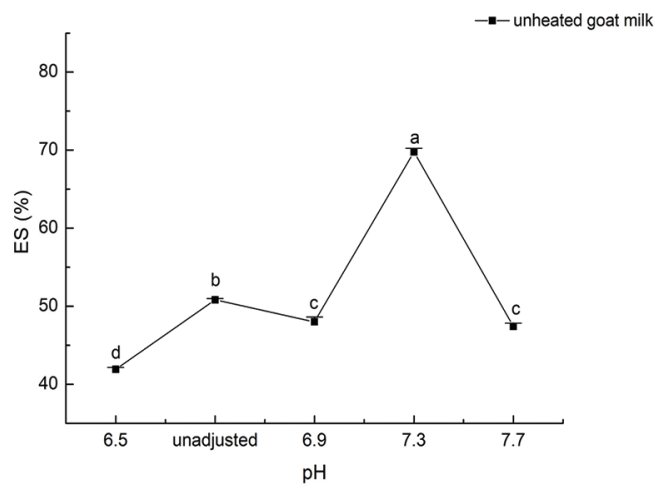

Figure 8. Changes induced by $\mathrm{pH}$ and heat on the emulsifying properties of goat milk proteins. EAI $=$ emulsifying activity index; ES $=$ emulsion stability. Values of each group not sharing the same letters $(\mathrm{a}-\mathrm{e})$ are significantly different $(P<0.05)$, and error bars represent SD. 
A

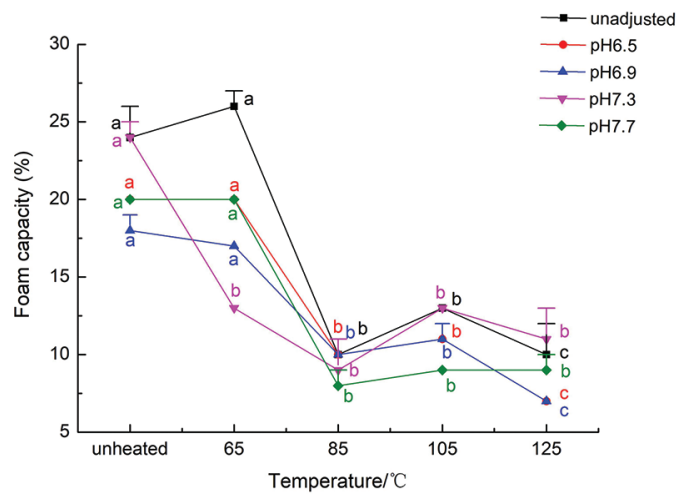

B

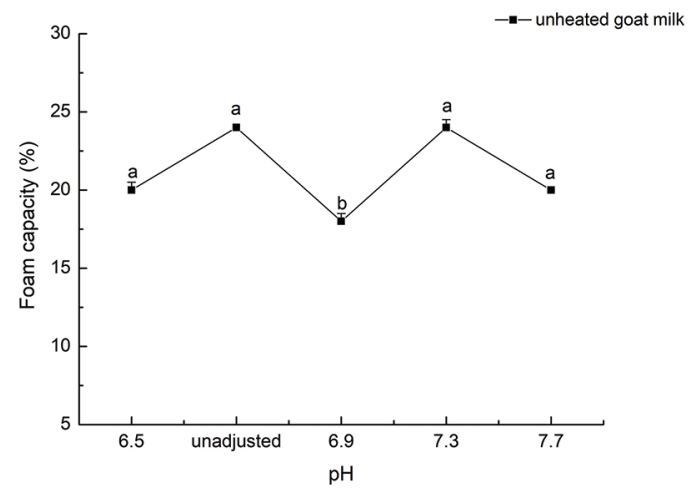

Figure 9. Changes induced by $\mathrm{pH}$ and heat on the foam capacity of goat milk proteins. Values of each group not sharing the same letters $(\mathrm{a}-\mathrm{c})$ are significantly different $(P<0.05)$, and error bars represent SD.

divalent cations, thus changing the ability of the proteins to bind water. At the same time, an appropriate heat treatment can cause the milk protein molecules to form soluble $\beta$-LG/K-casein polymers, which promote the formation of a protein gel network, and prevent water loss and thus improve the WHC of the proteins.

The $\mathrm{OHC}$ of goat milk proteins after heat treatment above $85^{\circ} \mathrm{C}$ were significantly higher than that of fresh goat milk protein $(P<0.05$; Figure $11 \mathrm{C})$. The reason might be that the appropriate heat treatment promoted the unfolding of the highly organized structure of the protein, exposure of the hydrophobic groups, increased flexible molecular segments, and more orderly arrangement of molecules, resulting in an increase in the $\mathrm{OHC}$ (Oliyae et al., 2017). The OHC of goat milk proteins at $\mathrm{pH} 6.9$ and 7.3 were superior to samples subjected to other $\mathrm{pH}$ conditions (Figure 11D). As a result, goat milk proteins at neutral $\mathrm{pH}$ had the best $\mathrm{OHC}$. The $\mathrm{OHC}$ of the treated groups were significantly affected by temperature, and the trend was different $(P<0.05)$.

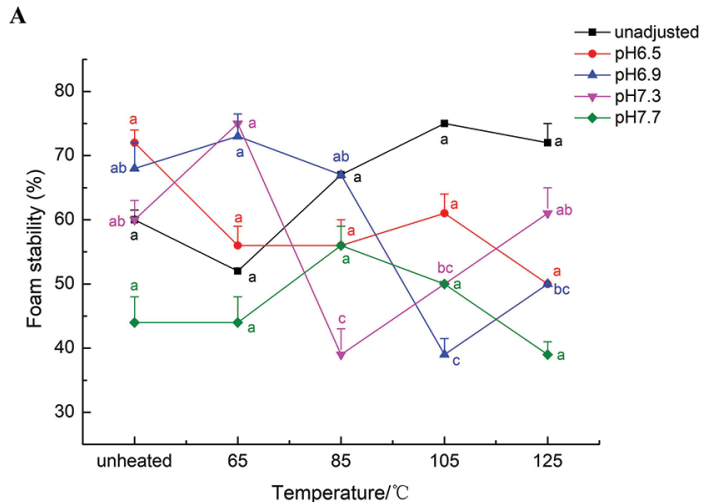

With the exception of $85^{\circ} \mathrm{C}$, the goat milk proteins at $\mathrm{pH} 6.5$ and 7.7 showed relatively good $\mathrm{OHC}$ during heat processing, and the goat milk protein at $\mathrm{pH} 6.5$ had the highest $\mathrm{OHC}$ at $105^{\circ} \mathrm{C}$. Zhang et al. (2017) indicated that the $\mathrm{OHC}$ of proteins were influenced by their hydrophobic groups. The $\mathrm{pH}$ influenced the distribution of hydrophobic groups on the inside and outside of the protein molecule. At the same time, different heat treatments can cause the dissociation of the protein molecules or heat-induced aggregation, which results in the exposure or protection of hydrophobic sites and affects the binding between proteins and oil, influencing the OHC (Alizadeh-Pasdar and Li-Chan, 2000).

\section{CONCLUSIONS}

In this study, the combination of $\mathrm{pH}$ and heat treatment can significantly change the structural and functional properties of goat milk proteins, which were

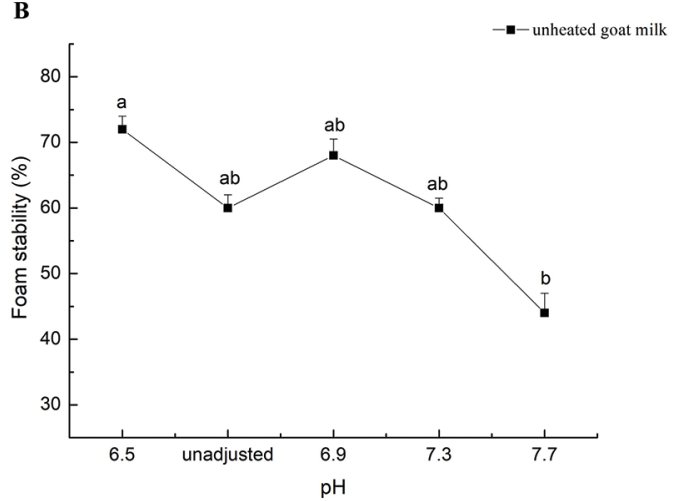

Figure 10. Changes induced by $\mathrm{pH}$ and heat on the foam stability of goat milk proteins. Values of each group not sharing the same letters $(\mathrm{a}-\mathrm{c})$ are significantly different $(P<0.05)$, and error bars represent SD. 
A

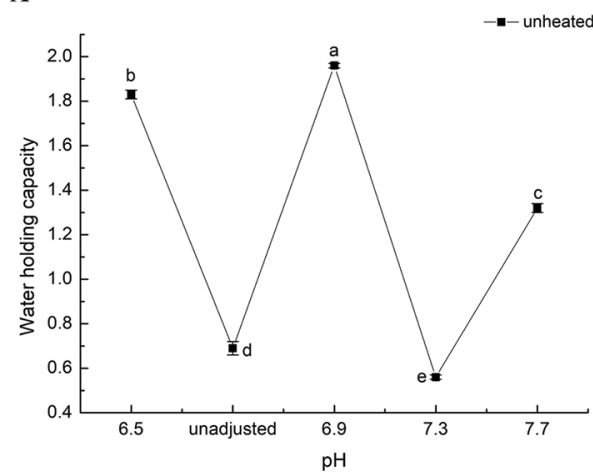

C

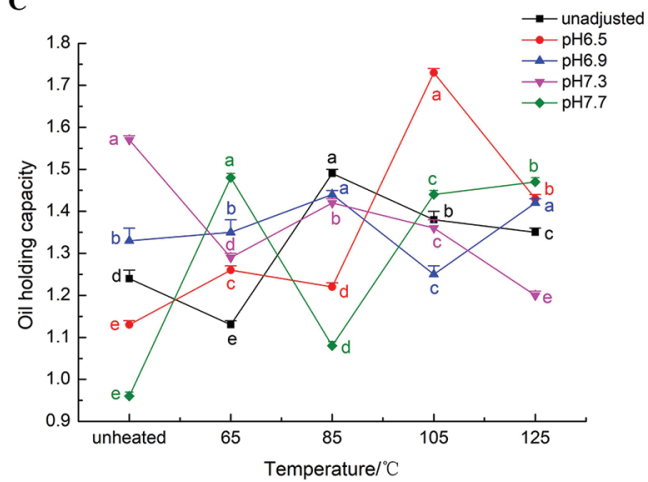

B

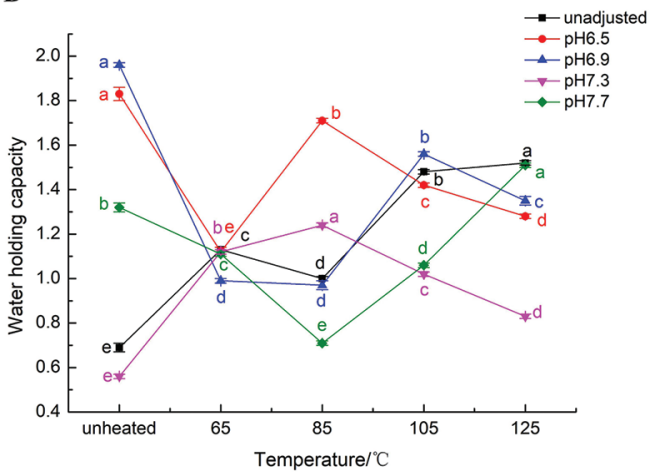

D

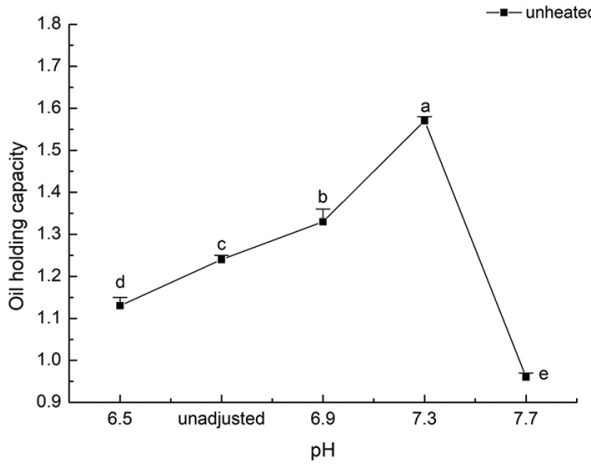

Figure 11. Changes induced by $\mathrm{pH}$ and heat on the water-holding capacity and oil-holding capacity values of goat milk proteins. Values of each group not sharing the same letters $(\mathrm{a}-\mathrm{e})$ are significantly different $(P<0.05)$, and error bars represent SD.

closely related to the dissociation and aggregation of casein and whey proteins and the interactions between them. The thermal stability of goat milk protein was significantly affected by $\mathrm{pH}$, and the thermal stability was the lowest when the $\mathrm{pH}$ was 7.7 . The $\mathrm{pH}$ and heat treatments had significant effects on the structural properties of goat milk the protein, such as their surface hydrophobicity, zeta potential, turbidity, secondary structure, and surface structure. In addition, under weakly acidic conditions, the goat milk proteins subjected to different heat treatments had better ESI, FC, FS, and WHC values. Under basic and neutral conditions, goat milk proteins subjected to different heat treatments had better $\mathrm{ES}$ and $\mathrm{OHC}$ values. In conclusion, the structural and functional properties of goat milk proteins were influenced by $\mathrm{pH}$ and heat. The processing conditions of goat milk proteins can be optimized by tuning the $\mathrm{pH}$ and heat conditions, which provides a theoretical basis for research into the applications of goat milk proteins.

\section{ACKNOWLEDGMENTS}

This work was supported by the Key Research and Development Program of Shandong Province
(2019YYSP025) and the National Natural Science Foundation of China (31501501).

\section{REFERENCES}

Alexander, M., L. F. Rojas-Ochoa, M. Leser, and P. Schurtenberger. 2002. Structure, dynamics, and optical properties of concentrated milk suspensions: An analogy to hard-sphere liquids. J. Colloid Interface Sci. 253:35-46. https://doi.org/10.1006/jcis.2002.8452.

Alizadeh-Pasdar, N., and E. C. Y. Li-Chan. 2000. Comparison of protein surface hydrophobicity measured at various $\mathrm{pH}$ values using three different fluorescent probes. J. Agric. Food Chem. 48:328334. https://doi.org/10.1021/jf990393p.

Anema, S. G., and H. Klostermeyer. 1997. Heat-induced, pH-dependent dissociation of casein micelles on heating reconstituted skim milk at temperatures below $100^{\circ}$ C. J. Agric. Food Chem. 45:11081115. https://doi.org/10.1021/jf960507m.

Barreto, P. L. M., A. T. N. Pires, and V. Soldi. 2003. Thermal degradation of edible films based on milk proteins and gelatin in inert atmosphere. Polym. Degrad. Stabil. 79:147-152. https://doi.org/ 10.1016/S0141-3910(02)00267-7.

Bevilacqua, C., P. Martin, C. Candalh, J. Fauquant, M. Piot, A.-M. Roucayrol, F. Pilla, and M. Heyman. 2001. Goats' milk of defective $\alpha_{\mathrm{S} 1}$-casein genotype decreases intestinal and systemic sensitization to $\beta$-lactoglobulin in guinea pigs. J. Dairy Res. 68:217-227. https://doi.org/10.1017/S0022029901004861.

Chen, D., X. Li, X. Zhao, Y. Qin, J. Wang, and C. Wang. 2019a. Comparative proteomics of goat milk during heated processing. Food Chem. 275:504-514. https://doi.org/10.1016/j.foodchem.2018.09 .129 .

Chen, D., X. Y. Li, X. Zhao, Y. S. Qin, X. X. Zhang, J. Li, J. M. Wang, and C. F. Wang. 2019b. Proteomics and microstructure 
profiling of goat milk protein after homogenization. J. Dairy Sci. 102:3839-3850. https://doi.org/10.3168/jds.2018-15363.

Chen, D., X. Zhao, X. Li, J. Wang, and C. Wang. 2018a. Milk compositional changes of Laoshan goat milk from partum up to 261 days postpartum. Anim. Sci. J. 89:1355-1363. https://doi.org/10.1111/ asj.13062.

Chen, L., Y. Li, J. Han, D. Yuan, Z. Lu, and L. Zhang. 2018b. Influence of transglutaminase-induced modification of milk protein concentrate (MPC) on yoghurt texture. Int. Dairy J. 78:65-72. https: //doi.org/10.1016/j.idairyj.2017.10.001.

Choudhary, S., S. Arora, A. Kumari, V. Narwal, and V. Sharma. 2018. Effect of type and quality of milk on heat induced protein-protein interactions in khoa. J. Food Sci. Technol. 55:4321-4329. https:// doi.org/10.1007/s13197-018-3380-y.

Damodaran, S. 1996. Amino acids, peptides, and protein. Pages 321429 in Food Chemistry. 3rd ed. O. R. Fennema, ed. Marcel Dekker, New York, NY.

del Angel, C. R., and D. G. Dalgleish. 2006. Structures and some properties of soluble protein complexes formed by the heating of reconstituted skim milk powder. Food Res. Int. 39:472-479. https: //doi.org/10.1016/j.foodres.2005.09.010.

El Oudiani, A. E., S. Msahli, and F. Sakli. 2017. In-depth study of agave fiber structure using Fourier transform infrared spectroscopy. Carbohydr. Polym. 164:242-248. https://doi.org/10.1016/j .carbpol.2017.01.091.

Fennema, O. R., ed. 1996. Food Chemistry. 3rd ed. Food Science and Technology (USA). no. 76. Marcel Dekker Inc., New York, NY.

García, V., S. Rovira, K. Boutoial, and M. B. López. 2014. Improvements in goat milk quality: A review. Small Rumin. Res. 121:5157. https://doi.org/10.1016/j.smallrumres.2013.12.034.

Hoffmann, M. A. M., and P. J. J. M. Van Mil. 1999. Heat-induced aggregation of $\beta$-lactoglobulin as a function of $\mathrm{pH}$. J. Agric. Food Chem. 47:1898-1905.

Jackson, M., and H. H. Mantsch. 1995. The use and misuse of FTIR spectroscopy in the determination of protein structure. Crit. Rev. Biochem. Mol. Biol. 30:95-120. https://doi.org/10.3109/ 10409239509085140.

Jean, K., M. Renan, M. H. Famelart, and F. Guyomarc'h. 2006. Structure and surface properties of the serum heat-induced protein aggregates isolated from heated skim milk. Int. Dairy J. 16:303-315. https://doi.org/10.1016/j.idairyj.2005.04.001.

Kato, A., N. Tsutsui, N. Matsudomi, K. Kobayashi, and S. Nakai. 1981. Effects of partial denaturation on surface properties of ovalbumin and lysozyme. Nippon Nogeikagaku Kaishi 45:2755-2760.

Lajnaf, R., L. Picart-Palmade, H. Attia, S. Marchesseau, and M. A. Ayadi. 2017. The effect of $\mathrm{pH}$ and heat treatments on the foaming properties of purified $\alpha$-lactalbumin from camel milk. Colloids Surf. B Biointerfaces 156:55-61. https://doi.org/10.1016/j.colsurfb 2017.05.002

Lajnaf, R., L. Picart-Palmade, E. Cases, H. Attia, S. Marchesseau, and M. A. Ayadi. 2018. The foaming properties of camel and bovine whey: The impact of $\mathrm{pH}$ and heat treatment. Food Chem. 240:295-303. https://doi.org/10.1016/j.foodchem.2017.07.064.

Lam, R. S. H., and M. T. Nickerson. 2015. The effect of $\mathrm{pH}$ and temperature pre-treatments on the physicochemical and emulsifying properties of whey protein isolate. Lebensm. Wiss. Technol. 60:427-434. https://doi.org/10.1016/j.lwt.2014.07.031.

Lara-Villoslada, F., M. Olivares, J. Jiménez, J. Boza, and J. Xaus. 2004. Goat milk is less immunogenic than cow milk in a murine model of atopy. J. Pediatr. Gastroenterol. Nutr. 39:354-360. https: //doi.org/10.1097/00005176-200410000-00010.

Leeb, E., N. Haller, and U. Kulozik. 2018. Effect of pH on the reaction mechanism of thermal denaturation and aggregation of bovine B-lactoglobulin. Int. Dairy J. 78:103-111. https://doi.org/10.1016/ j.idairyj.2017.09.006.

Li, Q., M. Ying, S. He, W. Elfalleh, W. Xu, J. Wang, and L. Qiu. 2014. Effect of $\mathrm{pH}$ on heat stability of yak milk protein. Int. Dairy J. 35:102-105. https://doi.org/10.1016/j.idairyj.2013.10.015.

Lin, Y., A. L. Kelly, J. A. O'Mahony, and T. P. Guinee. 2018. Effects of milk heat treatment and solvent composition on physicochemical and selected functional characteristics of milk protein concentrate. J. Dairy Sci. 101:6799-6813. https://doi.org/10.3168/ jds.2017-14300.

Liu, R., S-M. Zao, S-B. Xiong, B-J. Xie, and L-H. Qin. 2008. Role of secondary structures in the gelation of porcine myosin at different $\mathrm{pH}$ values. Meat Sci. 80:632-639. https://doi.org/10.1016/j meatsci.2008.02.014.

Lou, X., J. Li, X. Zhang, J. Wang, and C. Wang. 2018. Variations in fatty acid composition of Laoshan goat milk from partum to 135 days postpartum. Anim. Sci. J. 89:1628-1638. https://doi.org/10 $.1111 /$ asj.13098.

Meena, G. S., A. K. Singh, S. Arora, S. Borad, R. Sharma, and V. K. Gupta. 2017. Physico-chemical, functional and rheological properties of milk protein concentrate 60 as affected by disodium phosphate addition, diafiltration and homogenization. J. Food Sci. Technol. 54:1678-1688. https://doi.org/10.1007/s13197-017-2600 $-1$.

Michel, A., M. Mestdagh, and M. A. V. Axelos. 1997. Physico-chemical properties of carrageenan gels in presence of various cations. Int. J. Biol. Macromol. 21:195-200. https://doi.org/10.1016/S0141 $-8130(97) 00061-5$.

Min, Y., W. Zhang, P. Wen, Z. Yan, and L. Qi. 2014. Heat stability of yak micellar casein as affected by heat treatment temperature and duration. Dairy Sci. Technol. 94:469-481. https://doi.org/10 $.1007 / \mathrm{s} 13594-014-0173-6$.

Montilla, A., and M. M. Calvo. 1997. Goat's milk stability during heat treatment: Effect of $\mathrm{pH}$ and phosphates. J. Agric. Food Chem. 45:931-934. https://doi.org/10.1021/jf960667y.

Morand, M., F. Guyomarc'h, S. Pezennec, and M.-H. Famelart. 2011. On how k-casein affects the interactions between the heat-induced whey protein/k-casein complexes and the casein micelles during the acid gelation of skim milk. Int. Dairy J. 21:670-678. https:// doi.org/10.1016/j.idairyj.2011.01.012.

Nair, P., D. G. Dalgleish, and M. Corredig. 2013. Colloidal properties of concentrated heated milk. Soft Matter 9:3815-3824. https://doi .org/10.1039/c2sm27540f.

O'Brien, R. W., D. W. Cannon, and W. N. Rowlands. 1995. Electroacoustic determination of particle size and zeta potential. J. Colloid Interface Sci. 173:406-418. https://doi.org/10.1006/jcis.1995 .1341 .

Oliyae, N., M. Ghorbani, M. Moosavi-Nasab, A. R. Sadeghimahoonak, and Y. Maghsoudloo. 2017. Effect of temperature and alkaline $\mathrm{pH}$ on the physicochemical properties of the protein isolates extracted from the whole ungutted lanterfish. J. Aquat. Food Prod. Technol. 26:1134-1143. https://doi.org/10.1080/10498850.2014.940564.

On-Nom, N., A. S. Grandison, and M. J. Lewis. 2010. Measurement of ionic calcium, $\mathrm{pH}$, and soluble divalent cations in milk at high temperature. J. Dairy Sci. 93:515-523. https://doi.org/10.3168/ jds.2009-2634.

Pacheco-Aguilar, R., M. A. Mazorra-Manzano, and J. C. RamírezSuárez. 2008. Functional properties of fish protein hydrolysates from Pacific whiting (Merluccius productus) muscle produced by a commercial protease. Food Chem. 109:782-789. https://doi.org/10 $.1016 /$ j.foodchem.2008.01.047.

Partschefeld, C., U. Schwarzenbolz, S. Richter, and T. Henle. 2007. Crosslinking of casein by microbial transglutaminase and its resulting influence on the stability of micelle structure. Biotechnol. J. 2:456-461. https://doi.org/10.1002/biot.200600232.

Pearce, N., and J. E. Kinsella. 1978. Emulsifying properties of proteins: Evaluation of a turbidimetric technique. J. Agric. Food Chem. 26:716-723. https://doi.org/10.1021/jf60217a041.

Ptiček Siročić, A. 2017. Characterization of casein fractions - Comparison of commercial casein and casein extracted from cow's milk. Chemical and Biochemical Engineering Quarterly Journal 30:501509. https://doi.org/10.15255/CABEQ.2015.2311.

Pugliese, A., M. Paciulli, E. Chiavaro, and G. Mucchetti. 2016. Characterization of commercial dried milk and some of its derivatives by differential scanning calorimetry. J. Therm. Anal. Calorim. 123:2583-2590. https://doi.org/10.1007/s10973-016-5243-y.

Raikos, V. 2010. Effect of heat treatment on milk protein functionality at emulsion interfaces. A review. Food Hydrocoll. 24:259-265. https://doi.org/10.1016/j.foodhyd.2009.10.014. 
Sauer, A., and C. I. Moraru. 2012. Heat stability of micellar casein concentrates as affected by temperature and $\mathrm{pH}$. J. Dairy Sci. 95:6339-6350. https://doi.org/10.3168/jds.2012-5706.

Shan, Y., M. Ma, X. Huang, Y. Guo, G. Jin, and Y. Jin. 2012. Simple $\mathrm{pH}$ treatment as an effective tool to improve the functional properties of ovomucin. J. Food Sci. 77:C740-C745. https://doi.org/10 $.1111 / \mathrm{j} .1750-3841.2012 .02761 . x$.

Shilpashree, B. G., S. Arora, P. Chawla, R. Vakkalagadda, and A. Sharma. 2015. Succinylation of sodium caseinate and its effect on physicochemical and functional properties of protein. Lebensm. Wiss. Technol. 64:1270-1277. https://doi.org/10.1016/j.lwt.2015 .07 .008 .

Stănciuc, N., G. Râpeanu, G. Bahrim, and I. Aprodu. 2012. pH and heat-induced structural changes of bovine apo- $\alpha$-lactalbumin. Food Chem. 131:956-963. https://doi.org/10.1016/j.foodchem 2011.09.087.

Vasbinder, A. J., and C. G. D. de Kruif. 2003. Casein-whey protein interactions in heated milk: The influence of $\mathrm{pH}$. Int. Dairy J. 13:669-677. https://doi.org/10.1016/S0958-6946(03)00120-1.

Vasbinder, A. J., F. van de Velde, and C. G. de Kruif. 2004. Gelation of casein-whey protein mixtures. J. Dairy Sci. 87:1167-1176. https: //doi.org/10.3168/jds.S0022-0302(04)73265-8.

Wagner, J., and J. Gueguen. 1999. Surface functional properties of native, acid-treated, and reduced soy glycinin. 1. Foaming properties. J. Agric. Food Chem. 47:2173-2180. https://doi.org/10.1021/ jf980977b.

Xu, W., S. He, M. Ying, Y. Zhang, Q. Li, L. Wang, and R. Wang. 2015. Effect of $\mathrm{pH}$ on the formation of serum heat-induced protein aggregates in heated yak milk. Int. J. Dairy Technol. 68:342-348. https://doi.org/10.1111/1471-0307.12218.
Yang, M., G. D. Zhang, J. T. Yang, D. Sun, P. C. Wen, and W. B. Zhang. 2018. Effect of $\mathrm{pH}$ on dissociation of casein micelles in yak skim milk. J. Dairy Sci. 101:2998-3007. https://doi.org/10.3168/ jds.2017-13653.

Yu, C., Y. Cha, F. Wu, X. Xu, Y. Qin, X. Li, and M. Du. 2018. Effects of high-pressure homogenisation on structural and functional properties of mussel (Mytilus edulis) protein isolate. Int. J. Food Sci. Technol. 53:1157-1165. https://doi.org/10.1111/ijfs.13690.

Yuksel, Z., E. Avci, and Y. K. Erdem. 2010. Characterization of binding interactions between green tea flavanoids and milk proteins. Food Chem. 121:450-456. https://doi.org/10.1016/j.foodchem .2009.12.064.

Zhang, L., L.-J. Wang, W. Jiang, and J.-Y. Qian. 2017. Effect of pulsed electric field on functional and structural properties of canola protein by pretreating seeds to elevate oil yield. Lebensm. Wiss. Technol. 84:73-81. https://doi.org/10.1016/j.lwt.2017.05.048.

Zhu, Y., J. Wang, and C. Wang. 2018. Research on the preparation, uniformity and stability of mixed standard substance for rapid detection of goat milk composition. Anim. Sci. J. 89:794-801. https: //doi.org/10.1111/asj.12985.

\section{ORCIDS}

X. Y. Li ๑ https://orcid.org/0000-0002-8332-3088

X. Zhao $\odot$ https://orcid.org/0000-0002-4615-4975

D. Chen (ㄴ) https://orcid.org/0000-0001-9866-6318

C. F. Wang (ㄴ) https://orcid.org/0000-0001-7992-6524 